ISSN 2338-4778 (Print)

ISSN 2548-4192 (Online)

Volume 8, Number 1, June 2020

pp. $67-79$

\title{
Existentialist Feminism of Woman's Struggle in Cigarette Girl Novel
}

\author{
Faidah Yusuf1, Muh. Iskandar Susilo ${ }^{2}$ \\ 1faidah.yusuf@uin-alauddin.ac.id \\ 2aiskandar501@gmail.com \\ ${ }^{1}$ English and Literature Department, Universitas Islam Negeri Makassar, Indonesia \\ ${ }^{2}$ English and Literature Department, Universitas Islam Negeri Makassar, Indonesia
}

Received: 28 March 2020 Accepted: 25 May 2020

DOI: $10.24256 /$ ideas.v8i1.1275

\begin{abstract}
Feminism is a movement of struggle to fight against all forms of objectification of women. The main character in the Cigarette Girl novel is a very independent woman. It was analyzed through feminism approach if the literary work is related to a woman as one of the characters in the story. The objective of this research is to describe the resistances of woman's struggle in Cigarette Girl Novel by Ratih Kumala. This reseacrh is analyzed by using descriptive qualitative method and used feminism approach to Beauvoir theory. The findings of this research are women can work, women can become intellectuals, and to transcend its boundaries. The result of this research that the women have same capability to survive in their lives as the men do therefore all the things that is point to them such as second sex, retarded, limited and weak go vague and even disappear because of the story which is told by the writer of the novel.

Keywords: Existentialist Feminism, Woman's Struggle, Cigarette Girl
\end{abstract}

\section{Introduction}

Feminism is women's Liberation ideology which is supported by all of the approaches that indicate women to get unfairness because of sex. This movement rose because the woman always supposed as the second sex and got the discrimination in the social life. It does not mean the extreme rebellion movement of woman to man, but to opposite the social caste and the paradigm of static myth in the social. Woman is not a weak creature because she has her own ability to get the position in the society. In the other word, this movement is the awareness of women about their identity to destruct the hierarchy that is harmful for woman's position, such as exploitation of woman, and also slavery by man. This content aspect is the stronger because it is only as a container or media (Djojosuroto, 2006). 
In literary works, women figures are often talked and used as imaging objects, because women are very interesting to talk. Women have two sides. On the other side women are cravings whose charms and can drive men crazy. On the other hand women are considered weak and the weaknesses are used as an excuse by bad men to exploit their beauty (Sugihastuti, 2010, Akmaliyah 2019; Ilzam, 2019). There is even the assumption that women are second-class human beings, who although they have beauty, do not have the same existence as men. Aristotle assumed that women were the sexes determined based on their lack of certain qualities and Aquinas argued that women were imperfect men. The existence of women means anything. The existence of women figure is not only a complement to a story but also a central figure of a literary work. The existence or self-actualization according to Maslow's term is the highest need that each individual wants to achieve. Each individual is certain to have a need for recognition of their existence in society, which then becomes one part of the community itself. The spirit of the realization of women who have existed continues to grow, even today.

Cigarette Girl is an interesting novel. It talks about Cigarette Girl, which is the existence, priceless in our country. Cigarette Girl has succeeded to prove as beautiful product. That is the existences reflect struggle of low class in this country. Why we cannot deny that in this age, we do recognize cigarette as a thing to break our body especially our health and waste our money. In other case, we can find in a cover of cigarette and advertisement commercial has warned very terrify; not only about writing "Smoking can cause cancer, heart attacks, impotence and pregnancy and fetal disorders" but also has changed "Smoking kills you" with disease pictures.

However, the researchers focus on the woman character in "Cigarette Girl" Novel that struggles to survive in economic condition after her husband was arrested because accused as one of rebels. Many cases come in her life but they are not obstacle for her. The women character in this novel tries to rise and prove that a woman has a power. the objective of this research is: To describe the resistances of woman's struggle in Cigarette Girl Novel by Ratih Kumala.

The significance of the research is to give information and contribute feminist literary to the readers. So, the reader can expect to recognize the struggle of woman which is implied in Cigarette Girl by Ratih Kumala The novel will be analyzed using a scalpel of Simone de Beauvoir's existentialism feminism. Existentialist feminism Simone de Beauvoir is used as an approach to express the way of being human (existence) then it will be analyzed how the forms of marginalization of women as others and how forms of resistance carried out by women as a form of existence. Furthermore, it will be analyzed and produced findings about the forms of marginalization of women as others and forms of resistance as a manifestation of the existence of female leaders in Novel Cigarette Girl by Ratih Kumala.

\section{Feminism}


One of the ways which women fights discrimination is through feminism. Lexically, Moeliono et.al (1993:241) stated that feminism is women's movement of demanding full equality between women and men, equality rights that covers all aspects of life, both in the political, economic, social and cultural. In other words, feminism is a women's movement to gain autonomy or freedom of self-determination. Merriam Webster in dictionary, feminism is the theory of the political, economic and social of the sexes. Organized activity on behalf of women's rights and interests. Feminism is a range of social movements, political movements and ideologies that share a common goal: to define, establish and achieve the political, economic, personal and social equality of the sexes.

According to Gamble, feminism incorporates the position that societies the male point of view and that woman are treated unfairly within those societies. Hannam (2007:22) In the book Feminism, the word feminism can be interpreted as: A recognition of the imbalance of power between the sexes, with the recognition of an imbalance of power between two sexes, with the role of women under men). Geofe (in Sugihastuti and Suharto, 2005) Feminism is an organized activity that fights for women's rights and interests. If women have equal rights with men, then women are free to determine themselves as they have done so far.

Feminist is a movement of struggle to fight against all forms of objectification of women. Women and men also are believed that they have differences in social awareness and social control (Anwar, 2010). Feminism focuses on history about the pressure and dominance of male power in every aspect of society, especially in literature. In literature, man creates images about women and women positions as compensation myths for men (Anwar, 2009: 50).

The boundaries related to feminism are indeed diverse and sometimes debated, starting from whether a person must be a woman, can be organizationally called feminist immediately, and up to where the level of awareness and knowledge regarding the form and root of the problem of injustice / discrimination, and how the person's future orientation. The gender studies, women studies or women assessments are appeared in all sorts program of studies. The assessments enhanced our knowledge about experience, importance, and women's life. Women study includes many topics that are related to women studies, such as women history, women labor, women physiological, lesbianism, etc.

\section{Existentialist Feminism}

Humans are responsible for being free to determine their choices (responsibility for choices) and responsible for the consequences of that choice (Sartre, 2002). As for the existentialists proposed by Simone de Beauvoir, Beauvoir said that women in their existence in this world only became liyan for men. Women are objects and men are the subject. So existentialism according to Beauvoir is when a woman is no longer an object but has become a subject for her.

a) The Relationship Subject-Object (The Others) 
De Beauvoir's ethical analysis highlights oppression and violence against humans caused by wrong understanding of the subject and object. Simone de Beauvoir argues that in human relations there is always an intersubjective conflict, each human being always tries to make another human being an object and does not want himself to be an object. The reason why women are oppressed is that their existence is ignored and not an absolute subject unlike men. Thus giving rise to the view that the absolute subject is men, while women are just other objects (other). The process starts from biological facts such as reproductive roles, hormonal imbalances, weakness of female organs, etc. that are combined with patriarchal history until finally women are cornered into reproductive and domestic roles and women are unwittingly led to the definition of unconscious beings. This is what makes domination of women throughout history.

The difference between women and men mostly comes from the fact that social construction marginalizes women and most of them are self-internalization (Otherness). The crucial question is whether women can free themselves from the status of objects and whether they must be men or can achieve different subjectivities. There is a culture created by men that assumes men as subjects and women as objects.

Women are always constructed by men, through male structures and institutions. But because women, like men, have no essence, women do not have to continue to be what men want. Women can also be as subjects, can be involved in positive activities in society. So that there is no more that can prevent women from building themselves and women can be creatures who have the essence and nature not underestimated (Beauvoir, 1989).

(Beauvoir, 1989) repeatedly said that although biological and psychological facts about women, for example, its main role in psychological reproduction relative to men's secondary roles, women's physical weakness relative to men's physical strength, and the inactive role they play in sexual relations is relative the active role of men can be right, but we judge facts to depend on us as social beings. We can see how women are made as number two creatures. Among them, women are used as nature, meaning women are as made objects of men because they are considered as a place for adventure. Women are also considered as objects that print children - even though women should be made as someone who can be invited to work together in life. From this we can see that there has been a marginalization of women.

b) Oppression of Women by Men

Gender oppression is not just a form of oppression. Far from that, black people know how it feels to be oppressed whites and poor people know what it's like to be suppressed by rich people. But according to Dorothy Kauffman McCall, women's oppression by men is unique for two reasons: 
1) Unlike racial and class oppression, oppression of women is a historical fact that is interconnected, an event in a time that is repeatedly questioned and distorted. Women are always subordinated by men.

2) Women have internalized a foreign perspective that men are essential and women are not essential.

Beauvoir labeled the actions of tragic women as women who accepted their interests as feminine mysteries, handed down from generation to generation. This personality, according to him, is attached to the institution of marriage and mather hood. He also argued that the marriage institution would actually damage the relationship of a couple and is a form of slavery, according to Beauvoir being a wife, mother or domestic worker is a feminem that limits women (Tong, 2004: 269).

Women decide to get married because it becomes an obligation, because of the pressure imposed on their shoulders, because marriage is the only most sensible solution, because they want a normal existence as a wife and mother, but a secret that is guarded and a feeling that depth will make the beginning of marriage life difficult, which may make life difficult, which may prevent the balance of happiness forever (Beauvoir, 1989: 237). Marriage is intended to avoid women from the freedom of men, but because there is no love or individuality without freedom, he must let go of love for special individuals to convince him to get life's protection from men (Beauvoir, 1989).

c) Three Types of Women According Beauvoir (1989)

According to (Beauvoir, 1989), although all women are involved in feminine role playing, there are three types of women who play the role of "women" to the top, namely as follows:

1) Prostitutes are those who are always willing to be objects for men, those who prostitute themselves not only for money, but also for the rewards that they get from men as a payment for their liyanan.

2) Narcissism, where most women become aware of their appearance so they try to improve their appearance which is actually a way for women to be beautiful for men to see. In other words, men will be more satisfied to make women their objects.

3) Mystics, are women who consider themselves better than other women because they obey the norms and values that apply in society, they are required to be ideal women.

In reflecting on the picture, of wives, mothers, working women, prostitutes, narcissists, and mystical women, Beauvoir concluded that the tragedy of all these roles, is that everything is not a construction built by women themselves. Women are likened to getting approval from the masculine world in productive society. Women are constructed by men through male structures and institutions, but because women like men also have no essence, women can also be subjects (Tong, 2004). To know the limits, women must refuse to internalize their faith. Because 
accepting Liyan can make a woman become an object, even a divided Self. For example, costumes and styles have cut off the feminine body and limited it from all possibilities for transcendence. One example of women's disunity is the phenomenon of whistles and male sexual comments on women which are usually resolved by women by trying not to think of it as a problem because it only concerns her body. So, women try to separate the mind and body. Therefore, women must refuse to become Liyan.

d) The Women Way Refuse Their Liyan

According to Beauvoir there are several strategies that can be implemented by women when they refuse their liyan. First women can work. Of course, Beauvoir realized that working in patriarchal capitalism was oppressive and exploitative, especially if the work made women have to do work in a double shiff: one shiff in the office or at the factory, and one other at home. Nevertheless, Beauvoir believes that no matter how hard and tiring the work of women is, work still provides various possibilities for women, who if not done women will lose that opportunity altogether. By working outside the house together with men, women can reclaim their transcendence "women will" concretely assert their status as subjects, as someone who actively determines the direction of his destiny. Second, women can become intellectuals, members of groups that will build change for women. Intellectual activity is an activity when a person thinks, sees and defines, and is not nonactivity when a person becomes the object of thought, observation, and definition. Beauvoir encouraged women to study writers such as Emily Bronte, Virgina Woolf, and Katherina Mansfield who truly valued themselves as writers by exploring the issues of death, life and suffering (Tong, 2004).

Third, women can work to achieve a socialist transformation of society. Like Sartre, Beauvoir has the same hope that the end of the subject-object conflict, the Self-Liyan among humans in general, among men and women in particular. not only that, Sartre and Beauvoir also assumed that one of the keys to liberation for women was economic power, one point he emphasized in his discussion about independent women. Beauvoir reminded women that the environment would limit them to defining themselves, women's freedom would also be limited by the amount of money they had in the bank.

Finally, to transcend its boundaries, women can refuse to internalize their liabilities by identifying themselves through the views of the dominant groups in society. Accepting the role of Liyan according to Beauvoir, is accepting the status of an object which means "rejecting the Self-Subject who is creative, and has autonomy towards himself" and takes the risk of experiencing insanity which is the result of involvement in continuing to lie (Tong, 2004: 276).

From some of the things described above, we can conclude that even women can fight against the marginalization that has happened to them through working, then becoming intellectual agents and the latter can work to achieve socialist social transformation. By examining novels in particular, analyzing female figures using 
the Existentialist Feminism approach, there are two things that will be analyzed first, the forms of marginalization of women as others, and the second forms of resistance as manifestations of existence.

\section{METHOD}

This reseacrh employed descriptive qualitative method. By using this method the researcher identified, described, and analyzed how the struggle of woman in Cigarette Girl novel by Ratih Kumala. Qualitative method can give more attention to data analysis, the data related with the context itself (Bahtiar, 2016). The source of data in this research is Cigarette Girl by Ratih Kumala. Published since in 2015. The novel consists of 15 chapter and 242 pages. The instrument use itself as an intstrument of the research by reading novel. The researcher make plan, collect data, note taking, analyze to report the results (Sugiyono, 2013). Researcher used content analysis technique that includes identification, to analyze the data, the researcher uses Simone de Beauvoir's theory about the existentialist feminsm, the aspects are used to analyze the data in order to enquire the struggle of woman that used in novel Cigarette Girl by Ratih Kumala.

\section{Result}

In this part the researcher took the data from Cigarette Girl novel after using note taking and classified, using the Beauvoir theory as follows the women way refuse their Liyan:

1) Women can work. Beauvoir realized that working in patriarchal capitalism was oppressive and exploitative, especially if the work made women have to do work in a double shiff: one shiff in the office or at the factory, and one other at home. Nevertheless, Beauvoir believes that no matter how hard and tiring the work of women is, work still provides various possibilities for women, who if not done women will lose that opportunity altogether. By working outside the house together with men, women can reclaim their transcendence "women will" concretely assert their status as subjects, as someone who actively determines the direction of his destiny.

Now, it was as if every mouthful of klobot smoke that Roemaisa inhaled reinvigorated her, while the sorrows that had piled up seemed to evaporate with every exhalation of smoke that came out of her mouth. Slowly but surely, Roemaisa recovered. She could not return to being the old Roemaisa, who was so feminine and obedient. The new Roemaisa was feisty. (D1, C4, P72-73)

The data shows the change in character experienced by Roemaisa after she lost her husband. After recovering from his sadness, he began a new life and became a new Roemaisa.

The sales of Lady Cigarettes skyrocketed, and Dasiyah grew busier and busier 
promoting the cigarettes at the occasional night fairs came to town not just in $M$ Town, but also Yogyakarta, Magelang, Solo, Kudus, and as far away as Lampung. Latters from Banyuwangi and Kalimantan came in, reporting that lady Cigarettes were selling well there too and asking for the rights to become city distributors there.

\section{(D2, C8, P134)}

The above quote proves that Dasiyah was able to prove her ability in selling and expanding the area of her family's inheritance products. Dasiyah was able to break her limits as a woman at that time to contribute to the family's economy.

2) Women can become intellectuals, members of groups that will build change for women. Intellectual activity is an activity when a person thinks, sees and defines, and is not nonactivity when a person becomes the object of thought, observation, and definition. Beauvoir encouraged women to study writers such as Emily Bronte, Virgina Woolf, and Katherina Mansfield who truly valued themselves as writers by exploring the issues of death, life and suffering (Tong, 2004: 274).

"Father, why don't you just focus on managing Independence! Cigarettes. Keep going with them." Dasiyah, who was now seventeen, advised her father one day. "There is already a market for Independence! All you have to do is develop it further, introduce it to new markets." "But it's new era, now, Yah." (D3, C8, P119)

The data above illustrates when Dasiyah expressed her opinion on her father who always wanted to create a new trademark. Dasiyah considers that her father's effort is futile because it will only use up capital. Dasiyah, who is still relatively young to her father, to continue Kretek Merdeka, which already has a name on the market.

3) Women can work to achieve a socialist transformation of society. Like Sartre, Beauvoir has the same hope that the end of the subject-object conflict, the Self-Liyan among humans in general, among men and women in particular. not only that, Sartre and Beauvoir also assumed that one of the keys to liberation for women was economic power, one point he emphasized in his discussion about independent women. Beauvoir reminded women that the environment would limit them to defining themselves, women's freedom would also be limited by the amount of money they had in the bank.

The girl was an able discussant in all matters of clove cigarettes. This, in fact, was enough to convince Pak Joko and his brother in law to invest in the company. If only those tingwe could be mass produced, then surely the two men would have given them an advance. But unfortunately, that wasn't possible and Idroes Moeria was left without an investor. (D4, C8, P126)

In the data above it says that this happened because the portrayal of the girl in general seemed timid when talking to the other person. It was also explained that Dasiyah was an intelligent woman who understood a variety of knowledge. 
She became quite popular amongst the other kiosk owners. Everyone knew that if there was one woman who ran a professional cigarette stand it was Dasiyah, or Jeng Yah, which was what everyone called her now. $(\mathbf{D 5}, \mathbf{C 8}, \mathbf{P 1 3 5})$

In the above quote, with his hard work managing cigarette products that his father pioneered, Dasiyah gained popularity in the community as the only woman who manages the professional cigarette business and eventually won the nickname "Jeng Yah". This proves that Dasiyah has become an independent woman as "Jeng Yah".

4) To transcend its boundaries, women can refuse to internalize their liabilities by identifying themselves through the views of the dominant groups in society. Accepting the role of Liyan according to Beauvoir, is accepting the status of an object which means "rejecting the Self-Subject who is creative, and has autonomy towards himself" and takes the risk of experiencing insanity which is the result of involvement in continuing to lie (Tong, 2004: 276).

She went looking for her husband's unsold klobot, took one of those cigarettes, lit it with a match, and inhaled deeply. (D6, C4, P72)

In the quote above shows that as a woman at that time Roemaisa seemed to defy her limits as an ordinary woman, where at that time women were considered weak and unequal to men.

Now, it was as if every mouthful of klobot smoke that Roemaisa inhaled reinvigorated her, while the sorrows that had piled up seemed to evaporate with every exhalation of smoke that came out of her mouth. Slowly but surely, Roemaisa recovered. She could not return to being the old Roemaisa, who was so feminine and obedient. The new Roemaisa was feisty. (D7, C4, P72-73)

The data shows the change in character experienced by Roemaisa after she lost her husband. After recovering from his sadness, he began a new life and became a new Roemaisa.

"Father, if you want to make a new cigarette, that means you have to make funds from Independence! If they fail, that means Independence! Production will suffer. And then what will we live on? How will we pay our workers?" Dasiyah was resolute. (D8, C8, P122)

The data says that as a girl who was given freedom by her father, Dasiyah finally became a critical girl. Dasiyah dared to express her opinion on matters concerning the future of her family's cigarette company. This proves that Dasiyah has surpassed the women of her time who tended to always accept men's decisions.

Dasiyah agreed, as long as her face wasn't on the label. Idroes Moeria agreed, and instead he drew a young woman who bore a striking resemblance to his daughter Dasiyah. She was wearing a lace kebaya blouse, her hair was pulled back in a small but neat chignon, and she was holding a lit cigarette with a wisp of smoke rising from its tip. Dasiyah's second stipulation was that she wanted to be involved in the making 
of the sauce. According to her, all the different sauces that had been used to all the different experimental cigarettes that had languished in the marked were way below the quality and taste of Independence! Cigarettes. (D9, C8, P131)

The data said that women as mixers of the kretek sauce formula were indeed a new thing to be found. This is because, basically formulating clove sauce formula requires a person to have a strong instinct and understanding of clove and its ingredients in detail.

Idroes Moeria no longer worried that his wife, Roemaisa hadn't given birth to any sons. It was enough for him that he had Dasiyah. The girl was not a tomboy at all, but she had the energy of a first-born son who coulsd take responsibility for the family. He could see that his daughter had wisdom and a good instinct that was useful when applied to their family cigarette business. (D10, C10, P154)

The above quote explains that, Dasiyah has been transformed as a woman who has more knowledge than girls usually about clove. This makes Moeria Idroes feel proud, even though he has a daughter as smart as Dasiyah even though at first he really wanted to have a son.

\section{Discussions}

In the novel Ciggarette girl depicted several female figures with abilities that exceed other women at that time. In this research, the writer only focused his research on the character of Roemasia and Dasiyah or Jeng Yah who have a strong character. Dasiyah, a young girl who has critical thinking, broad insights, capable trading abilities, and the ability to manage the financial aspects of her father's factory is a representation of women's struggle to show their existence in their lives.

\section{1) Women can work}

According to Beaviour, believes that no matter how hard and tiring the work of women is, work still provides various possibilities for women, who if not done women will lose that opportunity altogether. Roemaisi filled his days by selling klobot in the market and drug stores. The quote above shows the personality of a strong, independent, authoritative woman. Not necessarily, because her husband left a weak woman who can only cry Dasiyah has proven that she has exceeded the ability of women her age at that time to help the family economy.

\section{2) Women can become intellectuals}

According to Beauvoir, Intellectual activity is an activity when a person thinks, sees and defines, and is not nonactivity when a person becomes the object of thought, observation, and definition. Based on the theory above, the researcher found some evidence of a woman's struggle to shape her existence in society through her intelligence. The author discovers how Dasiyah actively and critically provided advice and input to her father regarding her father's plan to create a new trademark. It was considered as 
a pointless thing that would use up their capital. Inteleqtual activities are activities of thinking, seeing, and defining. Dasiyah as a young girl has all three aspects. The author found that Dasiyah criticized her father's actions when he wanted to create a new trademark by saying that the Kretek Merdeka brand had more historical value.. Dasiyah was able to see the historical value contained in the Merdeka kretek which according to her must be continued. There are 2 things the writer found. First, when women are called to take concrete actions, it means that women have thought ahead and can define the circumstances that occur. The result of this activity is the change in the view of the dominant group, in this case, the male presence of women. This is evidenced by the pride possessed by Idroes Moeria when he found Dasiyah, his daughter, who could do everything related to the kretek factory itself. Idroes Moeria no longer expects the boy he once coveted. Second, when women begin to express their opinions, it implies that women have internalized the other by overriding their limitations as women.

\section{3) To transcend its boundaries}

Women can refuse to internalize their liabilities by identifying themselves through the views of the dominant groups in society. The author seems to want to reject and criticize the public's view that a woman who smokes is a woman who is not good, whereas if the man who smokes it is seen as a natural thing. In this novel it is strongly contested. Roemasia fills his days by selling klobot in the market and drug stores. The quote above shows the personality of a strong, independent, authoritative woman. Not necessarily, because her husband left a weak woman who can only cry. Women in the view of society is a figure who placed as number two, backward, and limited. To achieve existence, women must cross the usual boundaries. Women must ensure that they are released from boundaries to achieve one

\section{Conclusion}

The woman has to be extra ordinary to exist, the researcher found three kinds of women struggle according to Beauvoir, as following women can work, women can become intellectuals, Women can work to achieve a socialist transformation of society, and to transcend its boundaries. There are some women characters who show differences from the other woman at that era those are Roemasia and Dasiyah or Jeng Yah, they as woman show strong will like men, they have control of their lives, so they do not want to hang to the man. In the novel Roemasia and Dasiyah or Jeng Yah have self-sufficiency and capability to manage and even to develop their life, in this case their social status researcher concludes that the women have same capability to survive in their lives as the men do therefore all the things that is point to them such as second sex, retarded, limited and weak go vague and even disappear because of the story which is told by the writer of the novel. The implication of this research could make the women know 
an daware that they have powerful to be strong and the same capability with the men.

\section{References}

Akmaliyah, A., Mohammad, R., \& Syafiq, M. (2019). Gender Equality in Teaching Materials of Arabic at Elementary School. IDEAS: Journal on English Language Teaching and Learning, Linguistics and Literature, 7(1). doi:https://doi.org/10.24256/ideas.v7i1.739

Awal, Hardiman. 2013. Thesis. Feminism Power in Suzanne Collins Novel's "Mocking Jay". Alauddin State Islamic University Makassar.

De Beauvoir, Simone. 2009. The Women Destroyed. London: Harpercollins Publishers.

De Beauvoir, Simone. 1989. The Second Sex. Translated and edited H. M. Parshley. New York: Vintage.

Djajanegara, Soenarjati. 2003. Kritik Sastra Feminis, Jakarta: PT. Gramedia Pustaka Utama.

Fraedman, Estelle B. 2002. No Turning Back: The Story of Feminism and the Future of Women. New York: Ballatine Books.

Gill, Richard. 1998. Mastering English Literature. New York: Macmilan Master Series.

Hannam, June. 2007. Feminism. Harlow, England: Pearson-Longman.

Humm, Maggie. 1998. Feminist Criticism: Women as Contemporary Critics. Brighton: Harvester Press.

Ilzam, M. (2019). Revealing Motives and Language Behavior in a Suicide Note. IDEAS: Journal on English Language Teaching and Learning, Linguistics and Literature, 7(1). doi:https://doi.org/10.24256/ideas.v7i1.737

Klarer, Mario. 1999. An Introduction to Literary Studies, $3^{\text {rd }}$ ed. New York: Routledge. Maryam. 2014. Thesis. The Reflection of Social Feminism in "Titanic" Movie. State University Makassar.

Muris, Maryam. 2013. Thesis. The Existentialism in Sarah Winman's Novel "When God Was A Rabbit". Alauddin State Islamic University Makassar.

Nurgiantoro, Burhan. 2007. Teori Pengkajian Fiksi. Yogyakarta: Gadjah Mada University Press.

Rasiah. 2015. Thesis. The Existence Heroine jane Eyre by Charlotte bronte.

Sartre, Jean Paul. 1992. Being and Nothingness. Gallimard, Philosophical Library.

Sudarni, Eka Serli. 2017. Thesis. Struggle of Woman in The Novel Sing Me to Sleep by Angela Morrison (The Analysis of Feminism). Alauddin State Islamic University Makassar.

Sugihastuti, Septiawan, ItsnaHadi. 2010. Gender dan Inferioritasi Perempuan (Praktik Kritik Sastra Feminis). Yogyakarta: Pustaka Pelajar.

Suharto, Sugihastuti. 2002. Kritik Sastra Feminis. Yogyakarta: Pustaka pelajar. 
IDEAS, Vol. 8, No. 1, June 2020

ISSN 2338-4778 (Print) ISSN 2548-4192 (Online)

Tong, Rosemarie Putnam. 1998. Feminism Thought: A More Comprehensive Introduction. University of North Caroline. United States of America: Westview Press.

Tuttle, Lisa. 1986. Encyclopedia of Feminism. Hanow Longman.

Ulfa. 2017. Thesis. Existentialism Reflected in Antagonist Character in "How to Train Your Dragon 2" Movie. Alauddin State Islamic University Makassar.

Usman. 2009. Conducted a study with the title "On the Exitence of Women" in Novel Throne Abidah El Khalieqy Work.

Wallstonecraft, Marry. 1972. The Right of Women. Courier Corporation.

Wellek, Rene and Austin, Warren. 1985. Theory of Literature. New York: Penguin Books Ltd.

Wallstonecraft, Marry. 1972. The Right of Women. Courier Corporation. 